(C) 2022, The Authors. Published by Elsevier Inc. and Fass Inc. on behalf of the American Dairy Science Association ${ }^{\circledR}$. This is an open access article under the CC BY license (http://creativecommons.org/licenses/by/4.0/).

\title{
Effect of dietary supplementation or cessation of magnesium-based alkalizers on milk fat output in dairy cows under milk fat depression conditions
}

\author{
A. Razzaghi, ${ }^{1 *}$ A. R. Vakili, ${ }^{1} \dagger$ B. Khorrami, ${ }^{2}$ M. H. Ghaffari, ${ }^{3}$ and D. E. Rico ${ }^{4}$ \\ ${ }^{1}$ Department of Animal Science, Faculty of Agriculture, Ferdowsi University of Mashhad, Mashhad 91775-1163, Iran \\ ${ }^{2}$ Department of Animal and Poultry Sciences, College of Aburaihan, University of Tehran, Tehran 3391653755, Iran \\ ${ }^{3}$ Institute of Animal Science, Physiology and Hygiene Unit, University of Bonn, 53115 Bonn, Germany \\ ${ }^{4}$ Centre de Recherche en Sciences Animales de Deschambault (CRSAD), Deschambault, QC, Canada, G0A 1S0
}

\section{ABSTRACT}

We aimed to evaluate the effects of dietary supplementation with magnesium oxide and calcium-magnesium dolomite on milk fat synthesis and milk fatty acid profile or persistency in milk fat synthesis after their cessation in dairy cows under milk fat depression conditions. Twenty-four multiparous dairy cows in early lactation (mean \pm standard deviation; $112 \pm 14 \mathrm{~d}$ in milk) were used in a randomized complete block design. Milk fat depression was induced in all cows for $10 \mathrm{~d}$ by feeding a diet containing $35.2 \%$ starch, $28.7 \%$ neutral detergent fiber, and $4.8 \%$ total fatty acid (dry matter). The experiment was conducted in 2 periods. During the Mg-supplementation period (d 1-20), cows were randomly assigned to (1) the milk fat depression diet used during the induction phase (control; $\mathrm{n}=8$ ), (2) the control diet plus $0.4 \%$ magnesium oxide (MG; $\mathrm{n}=$ 8 ), or (3) the control diet plus $0.8 \%$ calcium-magnesium dolomite (CMC; $\mathrm{n}=8)$. Compared with the control group, feeding the magnesium-supplemented diets increased milk fat concentration and yield by $12 \%$ within $4 \mathrm{~d}$. During the 20-d Mg-supplementation period, both the MG and CMC diets increased milk fat concentration and yield, as well as 3.5\% fat-corrected milk and energy-corrected milk yield, without affecting dry matter intake, milk yield, and milk protein and lactose concentrations. In the Mg-cessation period (d 21-30), all cows received the control diet, which resulted in a greater milk fat concentration and yield in the cows that had already received the MG and CMC diets in the Mg-supplementation period. Whereas, milk fat concentration and yield remained high after discontinuation of the magnesium-containing alkalizer until d 27 . The difference in milk fat synthesis was associated with

Received March 15, 2021.

Accepted October 7, 2021.

${ }^{*}$ Current address: Production Systems, Natural Resources Institute Finland (Luke), Jokioinen 31600, Finland.

†Corresponding author: savakili@um.ac.ir lower trans-10 C18:1 (-22\%) and higher trans-11 C18:1 $(+12.5 \%)$ concentrations in milk during the Mg-supplementation period. Furthermore, it was evident that within $2 \mathrm{~d}$ of supplementation, the trans-10:trans-11 ratio was lower in MG and CMC cows compared with cows receiving the control. This suggested that the effect of magnesium-based alkalizers on milk fat synthesis was mediated via a shift in ruminal biohydrogenation of cis-9,cis-12 C18:2 in the rumen. In conclusion, abrupt addition of magnesium oxide and calcium-magnesium dolomite increased milk fat synthesis, which persisted for $7 \mathrm{~d}$ after cessation of magnesium-based alkalizers. A similar ability to recover milk fat synthesis and normal fatty acid biohydrogenation pathways was observed for magnesium oxide and calcium-magnesium dolomite. Key words: magnesium, milk fat depression, transfatty acid, performance

\section{INTRODUCTION}

Increasing dietary NFC is a common approach to maximizing milk production in high-producing dairy cows. Typically, lactation diets for high-producing cows contain more than $40 \%$ NFC, mainly starch, which accounts for 70 to $80 \%$ of most cereal grains (NRC, 2001). Feeding highly fermentable carbohydrates results in increased concentration of VFA in the rumen and decreased rumen $\mathrm{pH}$, which can affect the microbial composition of the rumen (Calsamiglia et al., 1999; Dijkstra et al., 2012). These changes in rumen $\mathrm{pH}$ and microbiota composition are associated with shifts in rumen biohydrogenation (BH) pathways (Fuentes et al., 2009; Sandri et al., 2020), leading to increased rumen synthesis of $\mathrm{BH}$ intermediates capable of inducing milk fat depression (MFD), such as trans-10,cis-12 CLA and trans-9,cis-11 CLA (Baumgard et al., 2000; Perfield et al., 2007).

Magnesium oxide is the most common supplemental source of magnesium for dairy cows; however, feeding magnesium oxide in excess of the magnesium requirement established by the NRC (2001) can increase ru- 
men $\mathrm{pH}$ and milk fat synthesis in dairy cows (Erdman et al., 1982; Bach et al., 2018). This additional magnesium oxide supplementation may increase feeding costs, whereas alternative magnesium sources may have similar effects while being less expensive.

In vivo studies have shown that regulation of rumen $\mathrm{pH}$ by the addition of buffer reduces the production of BH intermediates associated with MFD (Kalscheur et al., 1997; Cabrita et al., 2009). Similarly, different types of magnesium-based alkalizers have been proposed to stabilize rumen $\mathrm{pH}$ and thus reduce the occurrence of MFD (Neville et al., 2019; Razzaghi et al., 2020). Bach et al. (2018) reported that a magnesium-based product can neutralize rumen $\mathrm{pH}$ and maintain milk fat content more efficiently than sodium bicarbonate when cows are challenged with $3 \mathrm{~kg} / \mathrm{d}$ of additional barley in the ration. In addition, feeding potassium carbonate sesquihydrate decreased trans-10 C18:1 content in milk [0.68 vs. $0.40 \%$ of total fatty acids (FA)] and increased milk fat synthesis (Harrison et al., 2012). Rauch et al. (2012) reported no difference in milk fat yield and feed efficiency between cows fed sodium bicarbonate or calcium-magnesium dolomite. Recently, we examined the diurnal rumen $\mathrm{pH}$ pattern by adding magnesium-based alkalizers when TMR formulated as potentially acidotic was fed to dairy cows and found that calcium-magnesium dolomite had a similar ability to magnesium oxide to shorten the time that rumen $\mathrm{pH}$ remained below 5.8 (from $12.5 \mathrm{~h} / \mathrm{d}$ in control group to 9.1 and $8.7 \mathrm{~h} / \mathrm{d}$, respectively; Razzaghi et al., 2021). The acid-neutralizing ability of magnesium oxide probably reflects adequate solubility in rumen fluid (Le Ruyet and Tucker, 1992; Schaefer et al., 1982), which allows alkalizer to be effective at low $\mathrm{pH}$ when cows are fed high-starch diets. A similar mechanism may be at work with calcium-magnesium dolomite, which provides a novel alkalizer that achieves similar effects to commonly used minerals, such as magnesium oxide, but at a lower cost.

Although the beneficial effect of magnesium sources on rumen $\mathrm{pH}$ and milk fat content has been studied, the effect of supplementation or cessation of dietary magnesium sources on milk fat synthesis under MFD conditions is not known. In our previous study, we investigated the effect of magnesium sources (magnesium oxide or calcium-magnesium dolomite) on rumen fermentation and daily rumen $\mathrm{pH}$ patterns; however, that study was not designed to measure changes in milk fat synthesis due to experimental conditions (Razzaghi et al., 2021). To the best of our knowledge, no study has evaluated the use of calcium-magnesium dolomite and magnesium oxide as the main alkalizers for the recovery from MFD. We hypothesized that calcium-magnesium dolomite acts as a buffer for rumen $\mathrm{pH}$ that favors nor- mal BH pathways and thus may promote recovery of milk fat synthesis. The main objective of the current study was to determine how rapidly magnesium oxide and calcium-magnesium dolomite supplementation may affect recovery of milk fat synthesis and ruminal $\mathrm{BH}$ intermediates in high-yielding dairy cows fed a milk fat-depressing diet. In addition, we aimed to evaluate the potential residual effects of magnesium-based supplements on milk fat synthesis after treatment cessation.

\section{MATERIALS AND METHODS}

\section{Cows, Experimental Design, and Treatments}

All experimental procedures and animal manipulations were approved by the Animal Care and Use Committee of Ferdowsi University of Mashhad (IACUC \#A20175) as described in Iranian Council of Animal Care (1995). Twenty-four multiparous Holstein cows $(660 \pm 14 \mathrm{~kg}$ of BW, $112 \pm 14$ DIM and $45 \pm 1.7$ $\mathrm{kg}$ of milk/d; mean $\pm \mathrm{SD}$ ) were used in a randomized complete block design. Cows were blocked according to parity, pre-experimental milk yield, and DIM. Sample size and power analyses were used to calculate (Morris, 1999) the minimum number of replicates needed per treatment $(\mathrm{n}=8)$ to detect a $10 \%$ level of observed mean differences for the primary outcome variables, including DMI and lactation performance, with a power of 0.80 and $\alpha=0.05$, using 8 replicates per treatment. Estimates of variation for these variables were based on previously reported values (Yu et al., 1998; AlfonsoAvila et al., 2017; Malekkhahi et al., 2021).

All cows were housed in individual tiestalls in the Rayner Dairy Teaching and Research Facility (Ferdowsi University of Mashhad, Mashhad, Iran) with free access to water at all times. Animals were fed the normal herd ration during a 7 -d pre-study period with forage-toconcentrate ratio of 40:60, formulated with $31.5 \% \mathrm{NDF}$, $16.7 \%$ CP, $31.6 \%$ starch (DM basis), and minerals and vitamins as recommended by the NRC (2001). Corn silage, alfalfa silage, and chopped alfalfa hay were used as forage components. Alfalfa hay was chopped to a theoretical length of $30 \mathrm{~mm}$ before feeding using a harvesting machine equipped with a sieve size controller (Golchin Trasher Hay Co.). The primary starch source during the pre-study period was dry ground corn.

Thereafter, during the 10-d MFD period, dairy cows were fed the milk fat-depressing diet with forage-toconcentrate ratio of 35:65 as a TMR, formulated with $35.5 \%$ starch, $29.0 \% \mathrm{NDF}$, and $4.8 \%$ total FA. The MFD diet contained $3.2 \%$ roasted soybeans (cracked) as a source of UFA and $38.5 \%$ of a processed corn product (DM basis) as a primary starch source (Table 
1). Corn grain processing (i.e., super-conditioning process) was carried out by placing the ground corn in the super-conditioner (model 680 Dabbel, Asiab Machine Iranian) and injecting steam to increase the moisture content to 18 to $20 \%$ along with cooking at $95^{\circ} \mathrm{C}$ for 6 min as explained by Malekkhahi et al. (2021).

After the MFD-induction period (for $10 \mathrm{~d}$ ), the cows began the experimental phase, which consisted of 2 periods, period 1 (Mg supplementation, d 1-20) and period 2 (Mg cessation, d 21-30). In the Mg-supplementation period, cows were randomly assigned to 1 of 3 treatments as follows: (1) MFD diet (CTRL), (2) the MFD diet $+0.4 \% \mathrm{DM}$ magnesium oxide (including $67 \%$ magnesium oxide; $\mathbf{M G}$ ), and (3) the MFD diet $+0.8 \% \mathrm{DM}$ calcium-magnesium dolomite (a mixture of $53 \%$ calcium dolomite and $44 \%$ magnesium carbonate; CMC). Part of the wheat bran was replaced with $0.4 \%$ of diet DM as magnesium oxide, and calcium-magnesium dolomite replaced the limestone completely and wheat bran partially with $0.8 \%$ (diet DM basis). Magnesium oxide and calcium-magnesium dolomite doses were determined using the neutralization-capacity method proposed by Bach et al. (2018) and recently validated in dairy cows (Razzaghi et al., 2021). Accordingly, the magnesium oxide dose was set at half of the calcium-magnesium dolomite dose based on the expected neutralizing activity (the neutralizing capacity of magnesium oxide and calcium-magnesium dolomite was 36 and $20 \mathrm{mEq} / \mathrm{g}$, respectively). Feeding rates of magnesium oxide and calcium-magnesium dolomite were consistent with recommended rates used in commercial diets (Rauch et al., 2012; Bach et al., 2018). In addition, the neutralizing activity of magnesium sources in 5\% acetic acid was evaluated by measuring $\mathrm{pH}$ change according to Goff (2018; data not shown). Rations were formulated to be isoenergetic, isonitrogenous, and meet the nutrient requirements (NRC, 2001) of lactating dairy cows (weighing $660 \mathrm{~kg}$, milk yield $=45 \mathrm{~kg}$, fat concentration $=3.5 \%$, true protein concentration $=3.0 \%$, and intake $=27 \mathrm{~kg}$ of $\mathrm{DM} / \mathrm{d}$ ). During the Mg-cessation period, all cows were returned to the MFD diet for $\mathrm{d} 10$. Cows were fed individually at 0800,1600 , and $2400 \mathrm{~h}$ to achieve a refusal rate of $10 \%$ and to allow ad libitum intake. Twice-weekly forage samples were collected, and DM content was determined to allow adjustment of diets to maintain forage-to-concentrate ratio. All cows were milked 3 times daily at 0700, 1500, and $2300 \mathrm{~h}$.

\section{Experimental Measurements and Sampling}

Feed intake and milk yield and components were recorded daily throughout the experiment. Feed refusals were collected before the morning feeding and weighed daily. Samples of TMR were collected daily and pooled at 5-d intervals, then weighed, oven-dried at $60^{\circ} \mathrm{C}$ for $48 \mathrm{~h}$, and ground in a Wiley mill (standard model 4; Arthur H. Thomas Co.) to pass a 1-mm sieve. The procedures of AOAC International (2005) were used to measure DM by oven drying at $100^{\circ} \mathrm{C}$ for $24 \mathrm{~h}$ (method 934.01). Ash was determined by combustion at $600^{\circ} \mathrm{C}$ for $2 \mathrm{~h}$ (method 942.05; AOAC International, 2005), and ether extract content (method 920.39; AOAC International, 2005) was determined using a Soxhlet Gerhardt apparatus (model SE 416; Gerhardt). Crude protein (Kjeldahl $\mathrm{N} \times 6.25$ ) was determined by the block digestion method using a copper catalyst and steam distillation in boric acid (method 2001.11; AOAC International, 2005) with a 2100 Kjeltec distillation unit (Foss Inc.). Neutral detergent fiber and ADF were analyzed using the Fibertec System (1010 Heat Extractor) as described by Van Soest et al. (1991). The NDF and ADF values are reported inclusive of residual ash. Sodium sulfite and heat-stable $\alpha$-amylase (Sigma A3306, Sigma-Aldrich) were used for NDF analysis. Nonfiber carbohydrate content (\% DM) of the diets was calculated as $100-(\mathrm{NDF}+\mathrm{CP}+$ ether extract + ash $)$ (NRC, 2001). Total starch was determined according to the procedure of Hall et al. (1999). The total content of FA in the diet was determined by GC using nonadecanoic acid (C19:1) as an internal standard (Sukhija and Palmquist, 1988). Subsamples of the TMR were subjected to digestion in $\mathrm{HCO}_{3}(70 \%)+\mathrm{H}_{2} \mathrm{O}_{2}(30 \%)$ using a digestion block for mineral measurements according to the procedure described by Mills and Jones (1996). Concentrations of calcium, magnesium, phosphorus, potassium, sodium, and sulfur in the diet were determined by inductively coupled plasma optical emission spectrometry (ICP-OES, Optima 4300DV, Perkin Elmer). Chloride in TMR was determined by silver nitrate titration after extraction with $0.5 \%$ nitric acid.

Milk was collected daily from all 3 daily milkings, and samples were pooled proportionately based on milk weights. Daily pooled milk samples were stored at $4^{\circ} \mathrm{C}$ with a preservative (potassium bichromate) until the further determination of milk fat, protein, and lactose using the Milko-Scan 605 analyzer (Foss Electric). Additional milk samples were collected on the first 5 consecutive days of the Mg-supplementation period without preservative and stored at $-20^{\circ} \mathrm{C}$ until the end of the experiment for subsequent determination of the milk FA profile. Fat-corrected milk was estimated as $3.5 \% \mathrm{FCM}=(0.434 \times \mathrm{kg}$ of milk $)+(16.216 \times \mathrm{kg}$ of milk fat) (Erdman, 2011). Energy-corrected milk was calculated as $\mathrm{ECM}=(0.327 \times \mathrm{kg}$ of milk $)+(12.95$ $\times \mathrm{kg}$ of milk fat) $+(7.2 \times \mathrm{kg}$ of milk protein) (Orth, 1992). Feed efficiency was determined using $3.5 \%$ FCM/ DMI ( $\mathrm{kg}$ of $3.5 \% \mathrm{FCM}$ per $\mathrm{kg}$ of DMI) and ECM/DMI ( $\mathrm{kg}$ of ECM per $\mathrm{kg}$ of DMI). 
Table 1. Ingredient and nutrient composition of the experimental total mixed ration ${ }^{1}$

\begin{tabular}{|c|c|c|c|}
\hline \multirow[b]{2}{*}{ Item } & \multicolumn{3}{|c|}{ Dietary treatment ${ }^{2}$} \\
\hline & CTRL & MG & $\mathrm{CMC}$ \\
\hline \multicolumn{4}{|l|}{ Ingredient, $\%$ of $\mathrm{DM}$} \\
\hline Corn silage & 26.0 & 26.0 & 26.0 \\
\hline Alfalfa silage & 5.00 & 5.00 & 5.00 \\
\hline Alfalfa hay & 4.00 & 4.00 & 4.00 \\
\hline Processed corn ${ }^{3}$ & 38.5 & 38.5 & 38.5 \\
\hline Soybean meal, $44 \%$ CP & 10.0 & 10.0 & 10.0 \\
\hline Canola meal & 6.00 & 6.00 & 6.00 \\
\hline Fish meal & 1.30 & 1.30 & 1.30 \\
\hline Meat meal & 2.00 & 2.00 & 2.00 \\
\hline Roasted soybeans, cracked & 3.20 & 3.20 & 3.20 \\
\hline Wheat bran & 2.50 & 2.10 & 2.00 \\
\hline Vitamin and mineral premix ${ }^{4}$ & 1.00 & 1.00 & 1.00 \\
\hline Limestone & 0.30 & 0.30 & - \\
\hline Salt & 0.20 & 0.20 & 0.20 \\
\hline Magnesium oxide $^{5}$ & - & 0.40 & - \\
\hline Calcium-magnesium dolomite 6 & - & - & 0.80 \\
\hline \multicolumn{4}{|c|}{ Chemical composition (\% of DM, unless otherwise noted) } \\
\hline $\mathrm{NE}_{\mathrm{L}}{ }^{7} \mathrm{Mcal} / \mathrm{kg} \mathrm{DM}$ & 1.62 & 1.62 & 1.62 \\
\hline $\mathrm{DM}$ & 61.2 & 61.7 & 61.5 \\
\hline Ash & 6.53 & 7.45 & 7.26 \\
\hline NDF & 28.7 & 28.5 & 28.5 \\
\hline $\mathrm{ADF}$ & 17.8 & 17.7 & 17.7 \\
\hline $\mathrm{CP}$ & 16.6 & 16.7 & 16.6 \\
\hline Ether extract & 5.06 & 5.10 & 5.01 \\
\hline Total fatty acids & 4.80 & 4.85 & 4.83 \\
\hline Nonfiber carbohydrates & 46.7 & 46.6 & 46.6 \\
\hline Starch & 35.2 & 35.4 & 35.5 \\
\hline \multicolumn{4}{|l|}{ Minerals, \% of DM } \\
\hline Sodium & 1.20 & 1.21 & 1.21 \\
\hline Potassium & 1.21 & 1.20 & 1.22 \\
\hline Chloride & 0.33 & 0.33 & 0.33 \\
\hline Sulfur & 0.24 & 0.24 & 0.23 \\
\hline Calcium & 0.73 & 0.74 & 0.76 \\
\hline Magnesium & 0.23 & 0.42 & 0.32 \\
\hline Phosphorus & 0.52 & 0.51 & 0.51 \\
\hline DCAD ${ }^{8} \mathrm{mEq} / \mathrm{kg}$ of $\mathrm{DM}$ & 126 & 125 & 120 \\
\hline \multicolumn{4}{|l|}{ Fatty acids, $\mathrm{g} / 100 \mathrm{~g}$ of $\mathrm{FA}$} \\
\hline C12:0 & 0.54 & 0.58 & 0.60 \\
\hline C14:0 & 0.60 & 0.64 & 0.63 \\
\hline C16:0 & 25.2 & 24.8 & 24.9 \\
\hline $\mathrm{C} 16: 1$ & 0.44 & 0.48 & 0.45 \\
\hline C18:0 & 2.10 & 2.20 & 2.32 \\
\hline cis-9 C18:1 & 23.0 & 22.8 & 22.9 \\
\hline cis-11 C18:1 & 0.72 & 0.80 & 0.80 \\
\hline cis-9,cis-12 C18:2 & 37.0 & 37.2 & 37.1 \\
\hline cis-9,cis-12,cis-15 C18:3 & 10.4 & 10.5 & 10.3 \\
\hline
\end{tabular}

${ }^{1}$ Samples of the TMR were collected daily and pooled by 5-d intervals in the entire experiment.

${ }^{2} \mathrm{CTRL}=$ control (milk fat-depressing diet; no magnesium-based alkalizers); $\mathrm{MG}=0.4 \% \mathrm{DM}$ of magnesium oxide; $\mathrm{CMC}=0.8 \% \mathrm{DM}$ of calcium-magnesium dolomite.

${ }^{3}$ Super-conditioned corn (Dordaneh Khorasan-e-Razavi Animal Feed Co.). The geometric mean and SD of the particle size in processed corn was $1.50 \pm 0.23 \mathrm{~mm}$.

${ }^{4}$ Each kilogram of the vitamin-mineral premix contained the following (DM basis): vitamin A (50,000 IU), vitamin $\mathrm{D}_{3}(10,000 \mathrm{IU})$, vitamin $\mathrm{E}$ (4,000 IU), calcium (196 g), phosphorus (96 g), sodium (71 g), magnesium (19 $\mathrm{g})$, iron $(3 \mathrm{~g})$, copper $(0.3 \mathrm{~g})$, manganese $(2 \mathrm{~g})$, zinc $(3 \mathrm{~g})$, cobalt $(0.1 \mathrm{~g})$, iodine $(0.1 \mathrm{~g})$, and selenium $(0.001 \mathrm{~g})$. ${ }^{5}$ Contained $48 \%$ magnesium, $1.7 \%$ sodium, and $2.9 \%$ calcium.

${ }^{6}$ Contained $15 \%$ magnesium, $0.8 \%$ sodium, and $22.5 \%$ calcium.

${ }^{7}$ According to NRC (2001).

${ }^{8}$ According to NRC (2001).

For the analysis of milk FA, milk fat was extracted using the centrifugation technique described by Luna et al. (2005). The refrigerated raw milk sample was kept at $20^{\circ} \mathrm{C}$ for $20 \mathrm{~min}$ and centrifuged at $17,800 \times g$ for 30 min at $4^{\circ} \mathrm{C}$. The fat layer was transferred to a microtube and centrifuged at $19,300 \times g$ for 20 min at room 
temperature. After the second centrifugation, the top layer was kept for FA analysis of milk fat. Subsequently, the extracted lipids were subjected to base-catalyzed transmethylation with sodium methoxide to give FAME following the procedure described by Christie (1982) with modifications by Chouinard et al. (1999). Fatty acid methyl esters were then recovered in hexane and separated in a gas chromatograph (3400 Varian Star instrument, Varian Inc.) equipped with a CP-SIL-88 capillary column (Chrompack, $60 \mathrm{~m} \times 0.25 \mathrm{~mm}$, Varian) and a flame ionization detector with helium as the carrier gas. The column temperature was initially set at $50^{\circ} \mathrm{C}$ for $1 \mathrm{~min}$ and increased by $10^{\circ} \mathrm{C} / \mathrm{min}$ to $190^{\circ} \mathrm{C}$ for another $130 \mathrm{~min}$. The injector temperature was $280^{\circ} \mathrm{C}$, and that of the detector was set at $300^{\circ} \mathrm{C}$. The FAME peaks were identified by comparing their retention time with that of a standard mixture of 37 components FAME (Sigma-Aldrich, Supelco 18919-1AMP) and 60 individual FAME standards (Sigma-Aldrich).

\section{Statistical Analysis}

Before statistical analysis, the normality of data distribution was tested by the Shapiro-Wilk test using the UNIVARIATE procedure and evaluated visually by plotting residuals (PROC PLOT). Of the tested parameters, feed intake and milk yield and components were not normally distributed. Nonnormally distributed values were scaled using a $\log _{10}$ transformation to correct for heteroscedasticity and meet assumptions of normality (reported in Supplemental Table S1; https:/ /data.mendeley.com/datasets/ngszd7jrtz/1; Razzaghi, 2021). After the log-transformation, the distribution of the data was tested again, and the data were normally distributed. Least squares means were back-transformed to original units for interpretation of tables and figures (Table 2 and Figure 1). Data were analyzed as a randomized complete block design with the REPEATED statement in the MIXED procedure of SAS (version 9.4, SAS Institute Inc.) using the following model:

$$
\mathrm{Y}_{i j k l}=\mu+\mathrm{T}_{i}+\mathrm{D}_{j}+(\mathrm{T} \times \mathrm{D})_{i j}+\mathrm{A}\left({ }_{k}\right)_{l}+\mathrm{B}_{l}+\varepsilon_{i j k l}
$$

where $\mathrm{Y}_{i j k l}$ is the variable observed, $\mu$ is the overall mean, $\mathrm{T}_{i}$ is the fixed effect of treatment $(i=1-3), \mathrm{D}_{j}$ refers to fixed effect of time $(\mathrm{d}),(\mathrm{T} \times \mathrm{D})_{i j}$ is the fixed effect of the interaction, $\mathrm{A}\left({ }_{k}\right)_{l}$ is the random effect of cow $(k)$ within block $(l), \mathrm{B}_{l}$ is the random effect of block, and $\varepsilon_{i j k l}$ denotes the residual error. Feed intake and milk production or component values were analyzed for 3 discrete periods as $\mathrm{Mg}$ supplementation (d 1-20), Mg cessation (d 21-30), and overall (d 1-30). However, we reported $P$-values for the entire period, although data on milk FA profile were analyzed for $\mathrm{Mg}$ supplementation period (d 1-5). Three variance-covariance structures (autoregressive type 1, compound symmetry, and Toeplitz) were tested, and the first-order autoregressive covariance structure was determined as the most appropriate covariance structure for all repeated statements according to the Akaike and Bayesian information criteria. Main effects were declared significant at $P \leq 0.05$, and tendencies were declared at $0.05<P$ $\leq 0.10$. Interactions were declared significant at $P \leq$ 0.10 , and tendencies were declared at $0.10<P \leq 0.15$. The PDIFF option was used with Tukey adjustment to test for significance of multiple comparisons. The SLICE option in the LSMEANS statement was used to compare the treatments at a specific day when treatment by time interaction was significant.

\section{RESULTS}

Dry matter intake, milk yield, milk components, and milk efficiency during periods of $\mathrm{Mg}$ supplementation, $\mathrm{Mg}$ cessation, and overall are shown in Table 2, and transformed data are reported in Supplemental Table S1. The addition of magnesium oxide or calcium-magnesium dolomite did not affect DMI and milk yield, and there was no interaction between treatment and time for these variables throughout the period. The MG and CMC diets resulted in a greater $(P=0.01)$ milk fat concentration and yield, whereas the interaction between treatment and time was significant $(P<$ 0.01 ) for milk fat concentration, but only a trend for milk fat yield $(P=0.11)$. Such an increase in milk fat concentration was observed within the first $4 \mathrm{~d}$ of the Mg-supplementation period (Figure 1, panel A). It remained high throughout the rest of the $\mathrm{Mg}$ supplementation period and remained elevated after discontinuation of the magnesium-containing alkalizers until d 27. In addition, a similar pattern was observed for milk fat yield (Figure 1, panel B).

Treatment did not affect milk protein and lactose concentrations or yields throughout the period. The MG and CMC groups had greater yields of $3.5 \% \mathrm{FCM}$ $(P=0.03)$ and ECM $(P=0.04)$ throughout the period compared with CTRL, but we observed no interaction between treatment and time for these variables. Feed efficiency $(\mathrm{kg}$ of $\mathrm{FCM} / \mathrm{kg}$ of DMI) was greater $(P<$ 0.01) in cows fed MG and CMC than in cows fed CTRL for the entire period. In addition, ECM efficiency ( $\mathrm{kg}$ of $\mathrm{ECM} / \mathrm{kg}$ of DMI $)$ was lower $(P<0.01)$ for CTRL than for $\mathrm{MG}$ group.

The effects of treatments on the profile of milk FA during the period of Mg supplementation are summarized in Table 3. Treatment differences were observed 
Razzaghi et al.: MILK FAT DEPRESSION AND ALKALIZERS IN DAIRY COWS

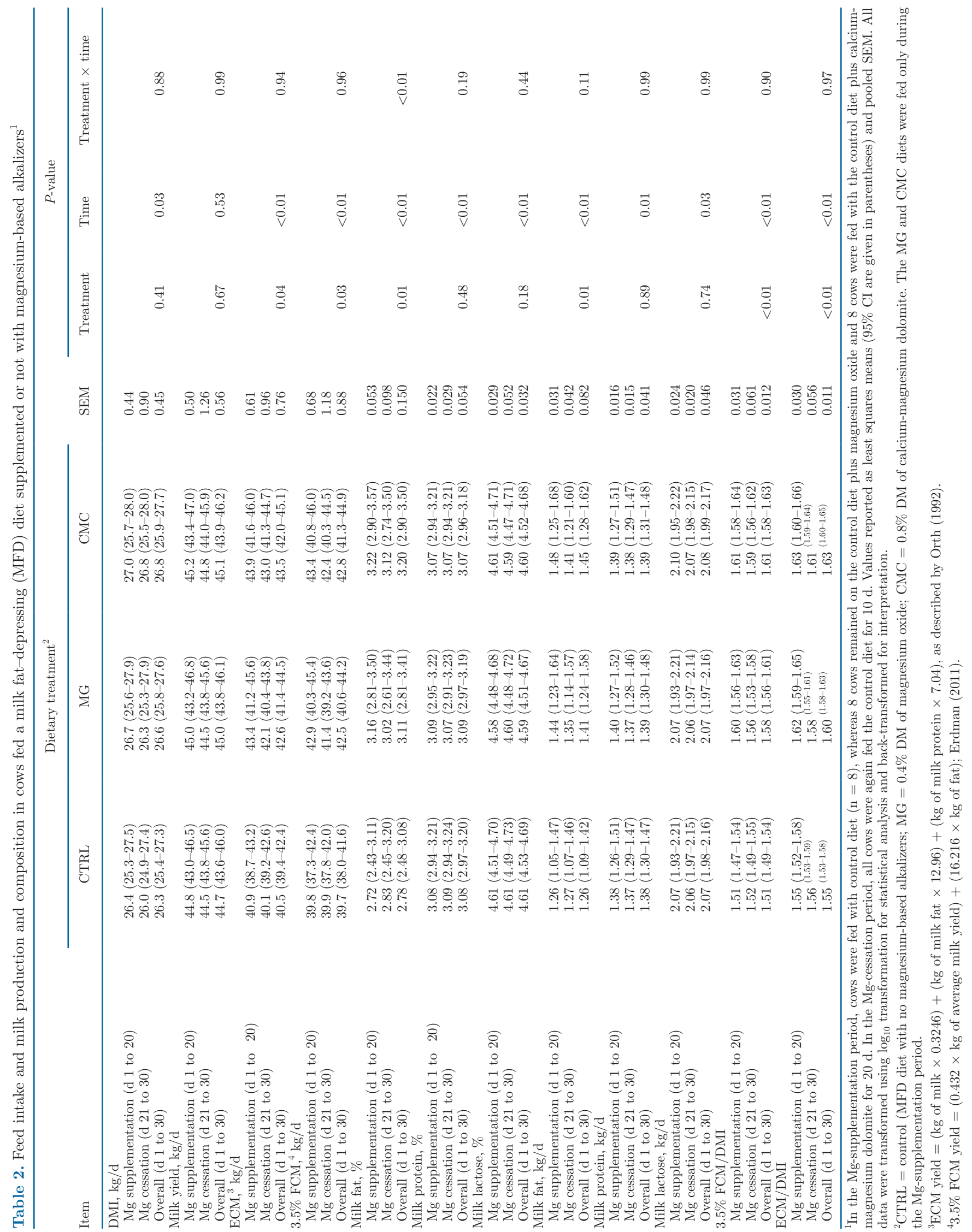


for the concentrations of $\mathrm{C} 6: 0$ (0.97 vs. 1.32, CTRL vs. $\mathrm{MG}$ and $\mathrm{CMC} ; P=0.02$ ), $\mathrm{C} 18: 0$ (11.5 vs. 12.4 , CTRL and MG vs. CMC; $P=0.02)$, trans-10 C18:1 (1.49 vs. 1.16 , CTRL vs. MG and CMC; $P<0.01$ ), and trans-11 C18:1 (1.54 vs. 1.78 , CTRL vs. MG; $P=0.01$ ) in milk fat. Although the concentration of C16:0 tended to increase $(P=0.10)$ in cows fed the MG $\operatorname{diet}(30.1$ vs. $31.2 \mathrm{~g} / 100 \mathrm{~g}$ of FA, CTRL vs. MG), the concentration of trans-9 C18:1 tended to decrease $(P=0.06)$ with feeding of the CMC diet (0.20 vs. $0.17 \mathrm{~g} / 100 \mathrm{~g}$ of FA, CTRL vs. CMC). The proportion of $\mathrm{C} 6: 0$ in milk fat increased $(+26 \%)$ in cows fed magnesium-based supplements compared with CTRL, whereas the proportion of C18:0 increased $(+7 \%)$ in cows fed the CMC diet compared with all other diets. Furthermore, trans-10 and trans-11 C18:1 concentrations in milk fat decreased $(-22 \%)$ and increased $(+12.5 \%)$, respectively, in cows receiving magnesium-based supplements compared with the CTRL group. In addition, dietary supplementation with magnesium-based alkalizers did not alter cis-9,trans-11 CLA milk fat concentrations. Magnesium supplementation reduced total trans-FA by $10.5 \%$ in cows fed the MG and CMC diets compared with those fed the CTRL diet. However, the proportions of milk de novo $(P=0.10)$ and mixed origin FA $(P=0.06)$ tended to increase in cows fed the MG diet compared with those fed the CTRL and CMC diets, but the concentration of preformed FA in milk was not affected by the treatments. The ratio of trans-10:trans-11 was also greater $(P<0.01)$ in CTRL compared with those fed $\mathrm{MG}$ and $\mathrm{CMC}$ diets.

An effect of time on milk FA profile was observed for C12:0, C14:0, trans-C14:1, cis-1C4:1, C18:0, and trans-C18:1 isomers $(P<0.05)$. Significant treatment $\times$ time interactions were observed for C18:0 and total trans-FA $(P<0.05)$ and the ratio of trans-10:trans-11 $(P<0.01)$. It was evident that within $48 \mathrm{~h}$ of supplementation, the ratio of trans-10:trans-11 was lower in cows fed MG and CMC compared with cows fed CTRL (Figure 2), which persisted in the remaining period of Mg supplementation (until d 5).

\section{DISCUSSION}

\section{Diets, Performance, and Milk Fat Synthesis}

In the present experiment, supplementation of magnesium in MFD-inducing diets attenuated the decrease in milk fat, an effect that gradually disappeared after cessation of magnesium supplementation. These changes were associated with improved $\mathrm{BH}$ characteristics and not with changes in DMI or milk yield. In fact, the addition of $0.4 \%$ magnesium oxide and $0.8 \%$ calciummagnesium dolomite to the diet did not affect feed in- take in our study. Other studies in lactating dairy cows showed that buffering or alkalizing agents had no effect on lactation performance, either in typical (Cabrita et al., 2009; Rauch et al., 2012) or high-concentrate diets (Kalscheur et al., 1997; Khorasani and Kennelly, 2001); however, other studies (Neville et al., 2019; Razzaghi et al., 2020) reported increased feed intake. Rauch et al. (2012) reported that there was no difference in feed intake and milk yield between control and calciummagnesium dolomite diets on commercial dairy farms, but differences in dietary starch and NDF contents compared with our study were evident $($ starch $=15.7$ vs. $35.2 \%$ and $\mathrm{NDF}=33.9$ vs. $28.7 \%$, on DM basis). In addition, there are divergent results regarding the effects of feeding buffers on milk yield. Some studies have documented no effects (Bach et al., 2018; Razzaghi et al., 2020), whereas others have reported increased milk yield (Razzaghi et al., 2021) with the addition of buffering or alkalizing agents.

In our study, MFD was intentionally induced using $38.5 \%$ DM of processed corn and $3.2 \%$ DM of cracked roasted soybeans in the experimental diets. The expectation was that greater ruminal starch degradability would lower rumen $\mathrm{pH}$, and this could account for any observed differences in the pattern of $\mathrm{BH}$ intermediates (Mohammed et al., 2010; Dewanckele et al., 2019). In addition, UFA was supplied in all diets via a slowly available FA from cracked roasted soybeans. The experimental diets contained an average of $28.6 \%$ NDF, 35.3\% starch, and 4.8\% total FA to induce MFD. Previous time course work has shown that changes in $\mathrm{BH}$ occur rapidly and a maximum MFD was observed within 10 to 14 d (Rico and Harvatine, 2013); therefore, the onset of MFD was expected within the duration of the MFD-induction period. In our study, the average milk fat concentrations at the beginning and end of the MFD-induction period were 3.82 and $2.75 \%$, and milk fat yields were 1.74 and $1.22 \mathrm{~kg} / \mathrm{d}$, respectively. This reflected a 28 and $30 \%$ reduction in milk fat concentration and yield, respectively, during the MFDinduction period. Similarly, Razzaghi et al. (2021) reported a greater milk fat concentration $(+11 \%)$ and yield $(+21 \%)$ when similar doses of calcium-magnesium dolomite and magnesium oxide $(0.8$ and $0.4 \%$ of the diet DM) were used compared with a nonsupplemented diet when cows were fed a $34.2 \%$ starch diet.

The objective of this experiment was to investigate the role of magnesium oxide and calcium-magnesium dolomite in relation to changes in milk fat synthesis after supplementation or cessation of dietary magnesiumbased alkalizers. In addition, the experimental diet was formulated to increase the risk of MFD, and thus CTRL cows had greater trans-10 C18:1 concentration in milk (1.49\% of FA), similar to a recent meta-analysis 

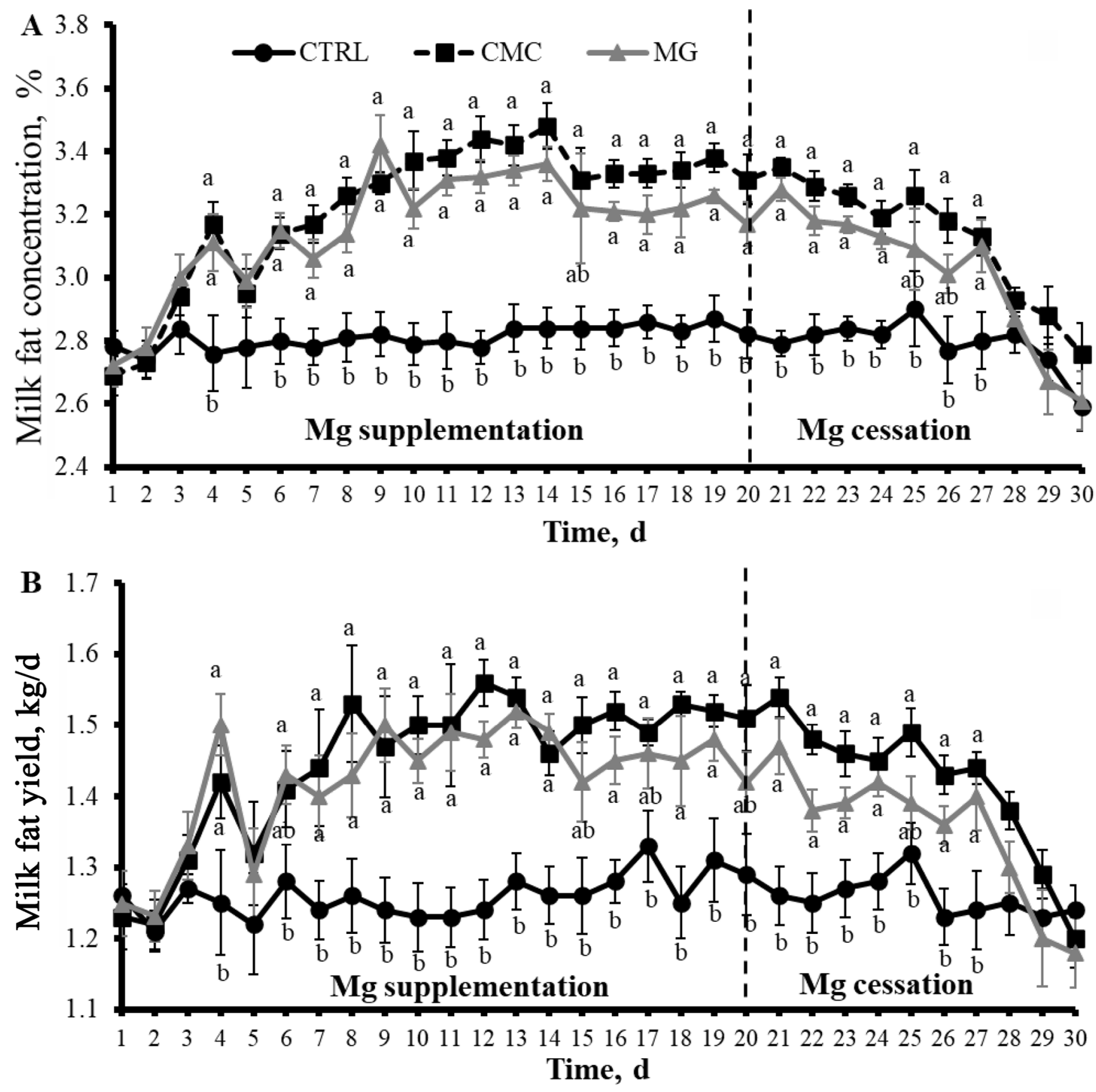

Figure 1. Milk fat concentration (\%, panel A) and milk fat yield (kg/d; panel B) during the Mg-supplementation period (d 1-20) for cows fed either a milk fat-depressing (MFD) diet alone (CTRL; $\bullet$ and solid line), the MFD diet $+0.4 \%$ magnesium oxide (MG; $\boldsymbol{\Delta}$ and solid line), or the MFD diet $+0.8 \%$ calcium-magnesium dolomite (CMC; and dotted line) and during the Mg-cessation period (d 21-30) when all cows received the MFD diet. Treatment $\times$ time interaction was $P<0.01$ for milk fat concentration and $P=0.11$ for milk fat yield. Different letters $(\mathrm{a}, \mathrm{b})$ indicate the significant difference $(P<0.05)$ between treatments within a time point. Milk fat values are back-transformed LSM, and error bars represent SEM.

of more than 500 treatment means (mean $=1.39 \%$ of FA; Matamoros et al., 2020). Moreover, milk fat yield of cows fed MG or CMC was greater after withdrawal of magnesium oxide and calcium-magnesium dolomite supplements than in the CTRL group (Figure 1, panel B). This suggested that the effects of the magnesium supplements on milk fat synthesis may have an effect on fat metabolism via altered $\mathrm{BH}$ pathways (i.e., trans-11 
C18:1 and trans-10 C18:1 shift). The timing (within 96 $\mathrm{h}$ ) of the increase in milk fat concentration induced by the addition of magnesium-based alkalizers is consistent with a previous report (Rico and Harvatine, 2013) of the timing of changes in milk fat concentration during the induction and recovery of diet-induced MFD. However, in the Mg cessation period, the positive effect of magnesium sources on milk fat synthesis disappeared by $7 \mathrm{~d}$ after cessation of magnesium supplementation until the end of the experiment. During the period of $\mathrm{Mg}$ supplementation, milk fat concentration and yield increased over time in both MG and CMC diets, but the recovery rate was slower than that of the potassium source in the study of Ma et al. (2017). They reported that recovery of MFD in dairy cows occurred within $2 \mathrm{~d}$ after supplementation of an MFD diet (contained 1.8\% soybean oil and $22 \%$ starch, DM-based) with $0.59 \%$ potassium carbonate sesquihydrate.

The magnesium-supplemented diets resulted in greater yields of ECM and 3.5\% FCM compared with the CTRL group, which is in agreement with the results of Razzaghi et al. (2021) and Khorasani and Kennelly

Table 3. Milk fatty acid profile in the first consecutive $5 \mathrm{~d}$ of $\mathrm{Mg}$-supplementation period for cows fed a milk fat-depressing (MFD) diet supplemented or not with magnesium-based alkalizers ${ }^{1}$

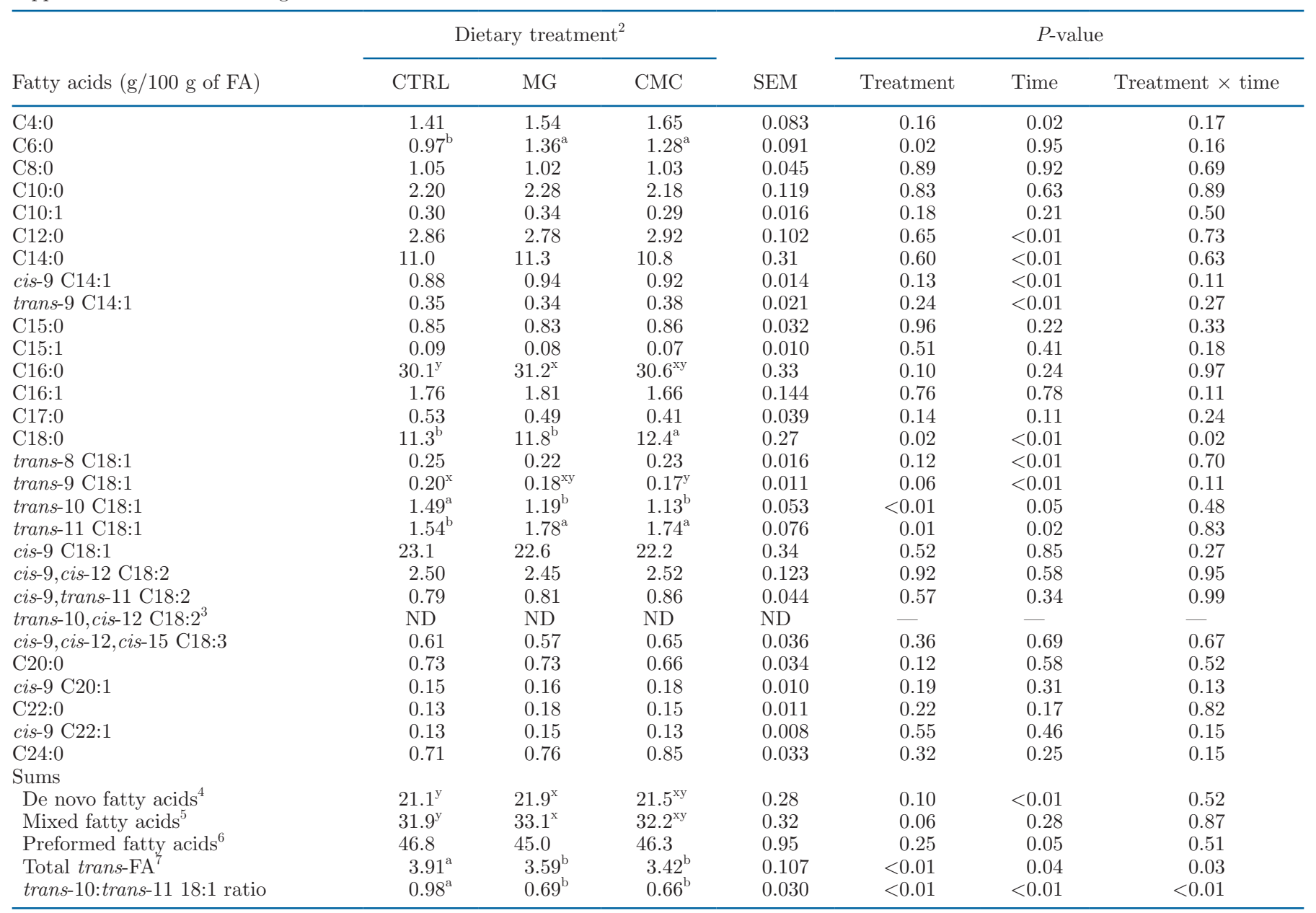

\footnotetext{
${ }^{\mathrm{a}, \mathrm{b}}$ Means with different superscripts within a row differ $(P<0.05)$.

${ }^{\mathrm{x}, \mathrm{y}}$ Means with different superscripts within a row differ $(P \leq 0.10)$. and 8 cows were fed with the control diet plus calcium-magnesium dolomite for $20 \mathrm{~d}$. calcium-magnesium dolomite.

${ }^{3}$ Trans-10, cis-12 CLA was not detected in milk fat (ND).

${ }^{4} \mathrm{Sum}$ of straight even-chain fatty acids from 4 to 14-carbon.

${ }^{5}$ Sum of $\mathrm{C} 16$ and C16:1.

${ }^{6}$ Sum of odd-chain fatty acids (C15:0), and all fatty acids with a chain length of 17-carbon and greater.

${ }^{7}$ Sum of trans-9 C14:1, trans-8 C18:1, trans-9 C18:1, trans-10 C18:1, trans-11 C18:1.
}

${ }^{1}$ In the Mg-supplementation period, cows were fed with control diet $(\mathrm{n}=8)$, whereas 8 cows remained on the control diet plus magnesium oxide

${ }^{2} \mathrm{CTRL}=$ control (milk fat depression diet with no magnesium-based alkalizers); $\mathrm{MG}=0.4 \%$ DM of magnesium oxide; $\mathrm{CMC}=0.8 \% \mathrm{DM}$ of 
(2001) that show higher milk fat yield. In addition, there was a difference in feed efficiency between magnesiumsupplemented diets and CTRL. Although MFD diets may provide more energy for adipose tissue instead of milk fat synthesis (Harvatine et al., 2009b), it appears that in our study, the improved feed efficiency may be a result of greater ECM yield and, ultimately, less energy being deposited in adipose tissue with similar feed intake. The specific mechanism of how magnesium-based alkalizer supplementation leads to increased milk fat synthesis could be attributed to enhanced triglyceride uptake by the mammary gland (Thomas and Emery, 1969) or changes in ruminal fermentation pattern (Erdman et al., 1982; Razzaghi et al., 2021). In the current study, increased milk fat synthesis may be related to the decreased milk concentrations of trans-10 C18:1 reported here, the shorter time in which rumen $\mathrm{pH}$ remains below a threshold (i.e., 5.8), and the greater acetate-to-propionate ratio as reported by Razzaghi et al. (2021). It is important to note that both the MG and $\mathrm{CMC}$ diets had lower concentrations of trans-10 C18:1 than the CTRL group ( -20 and $-24 \%$ in MG and $\mathrm{CMC}$, respectively), as both supplements could decrease the alternative BH pathway during MFD.

In one of the previous studies in which calciummagnesium dolomite was added to lactating dairy cow diet $(0.76 \%$ of diet DM), Rauch et al. (2012) reported that milk fat concentration was similar to the control treatment. Based on a few experiments, it appears that the addition of alkalizer to diets high in starch and corn silage in lactating cows may increase milk fat concentration due to the greater rumen solubility of alkalizer at lower rumen pH. Recently, Razzaghi et al. (2020) reported that a commercial buffer blend containing cation sources of calcium and magnesium increased milk fat concentration and yield in cows fed high-concentrate diets. The acid-neutralizing capacity of alkalizers is associated with some physical and chemical properties that explain the different rates of solubilization in rumen fluid (Le Ruyet and Tucker, 1992). In the present study, the neutralization capacity of magnesium oxide and calcium-magnesium dolomite were 36 and $20 \mathrm{mEq} \mathrm{H} \mathrm{H}^{+} / \mathrm{g}$, respectively, which is comparable to other studies (Crawford et al., 2008; Bach et al., 2018). Schaefer et al. (1982) suggested that the acid-neutralizing capacity of magnesium oxide probably depends on its solubility in rumen fluid. They observed that alkalizers were effective at low $\mathrm{pH}$ when cows were fed starch-rich diets. The results of an in vitro study with the buffer and alkalizer showed that the buffering capacity of the rumen fluid increased for magnesium oxide and stabilized over $24 \mathrm{~h}$, whereas this duration was 0 to $12 \mathrm{~h}$ for sodium bicarbonate, which can be attributed to a gradual dissolution of the alkalizer (Le Ruyet and Tucker, 1992). Fuentes et al. (2009) showed that the content of intermediates from incomplete $\mathrm{BH}$ in the rumen (trans-10 C18:1 and trans-10,cis-12 CLA) increased dramatically when the rumen $\mathrm{pH}$ decreased

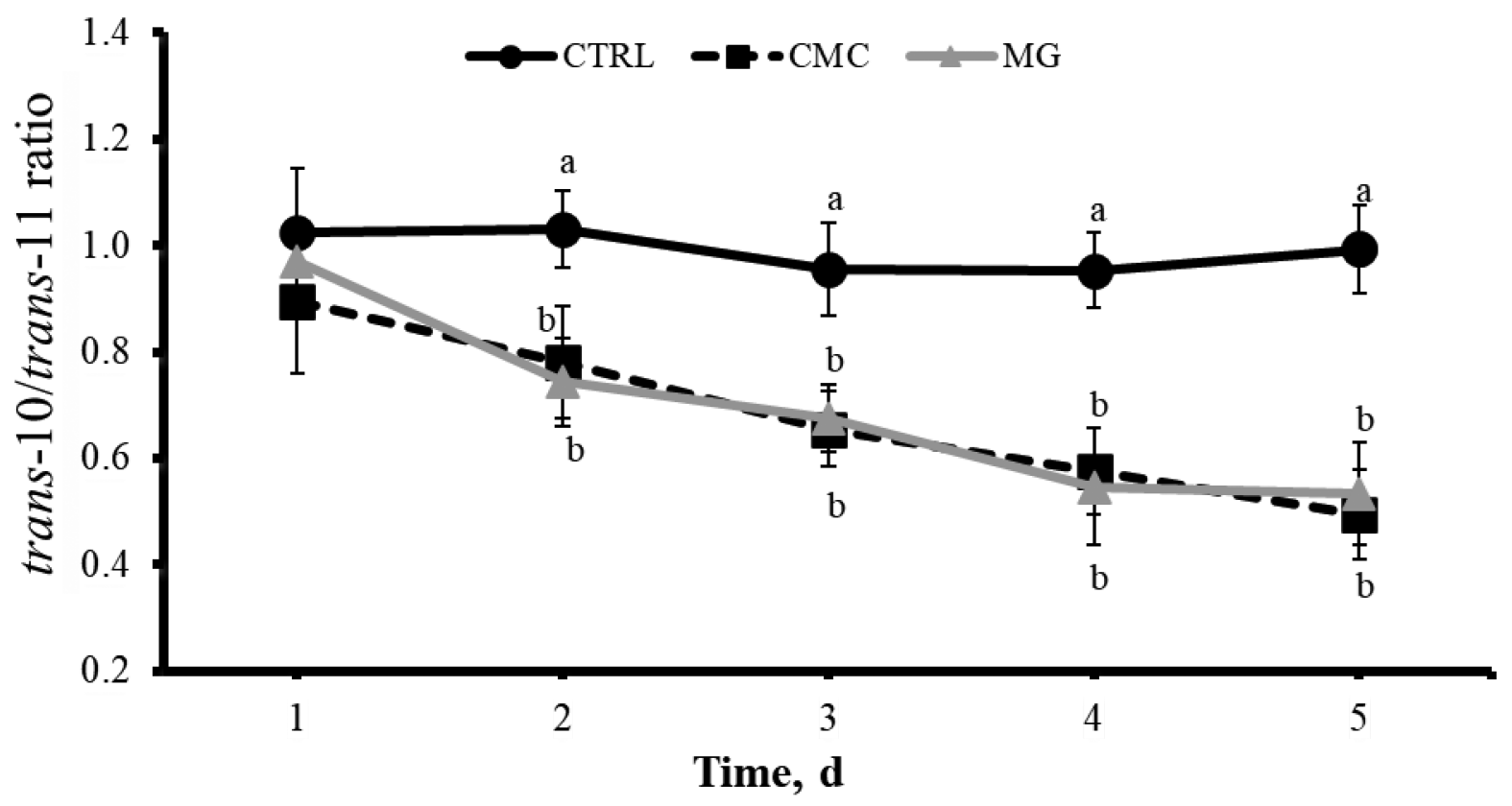

Figure 2. Trans-10:trans-11 ratio in milk fat during the first $5 \mathrm{~d}$ of the $\mathrm{Mg}$-supplementation period for cows fed either a milk fat-depressing (MFD) diet alone (CTRL; $\bullet$ and solid line), the MFD diet $+0.4 \%$ magnesium oxide (MG; $\boldsymbol{\Delta}$ and solid line), or the MFD diet $+0.8 \%$ calciummagnesium dolomite $(\mathrm{CMC} ; \boldsymbol{\square}$ and dotted line). Treatment $\times$ time interaction was $P<0.01$. Different letters (a.b) indicate the significant difference $(P<0.05)$ between treatments within a time point. Error bars represent SEM. 
from 6.4 to 5.6. Similarly, the decreased rumen $\mathrm{pH}$ in the CTRL group in the present study may have inhibited the activity of some rumen bacterial species believed to be critical for rumen BH (Jenkins et al., 2008) and consequently for the regulation of milk fat synthesis.

\section{Changes in Milk FA Profile}

Magnesium oxide and calcium-magnesium dolomite supplementation increased trans-11 C18:1 in milk fat by $12.5 \%$ compared with CTRL group, supporting the hypothesis that feeding magnesium-based alkalizers promote the normal (trans-11 C18:1) BH pathway (Bauman and Griinari, 2001; Rico and Harvatine, 2013) rather than the altered pathway (trans-10 C18:1). In the current study, it appeared that magnesium-based alkalizers promoted lower shifts in $\mathrm{BH}$, probably by controlling rumen $\mathrm{pH}$ and stimulating fiber-digesting rumen bacteria associated with normal BH (Jenkins et al., 2008). Among factors promoting the alternate pathway, a starch-rich diet may alter the rumen environment and promote a shift in $\mathrm{BH}$ pathways in favor of trans-10 C18:1 FA, regardless of dietary PUFA content (Rico et al., 2015; Sandri et al., 2020), in line with our results.

The concentration of cis-9,cis-12 C18:2 in milk fat was not affected by the treatments, suggesting that magnesium-based supplements do not affect the initial rate of isomerization, but rather shift $\mathrm{BH}$ pathways, as suggested by the increased concentrations of trans-10 C18:1. Trans-10,cis-12 CLA is one of the most potent inhibitors of milk fat synthesis (Shingfield and Griinari, 2007), but was not detected in milk fat in the present study. Importantly, this does not necessarily mean that trans-10,cis-12 CLA was not synthesized in the rumen, but only that these levels were not sufficient to be above the detection limit under our conditions. Furthermore, the levels of trans-10 C18:1 (average 1.27\% of FA) were very low compared with other studies, where they can reach levels of up to $4.0 \%$ of FA under MFD conditions (Rico and Harvatine, 2013), suggesting that less substrate was available for $\mathrm{BH}$ via this pathway. This is likely the result of the lower dietary levels of PUFA in our experiment (sum of C18:2 and C18:3 FA in the diet; $2.2 \%$ of DM) compared with the study of Rico and Harvatine (2013; $3.8 \%$ of diet FA). In addition, others have reported a transient reduction in milk fat synthesis in the absence of trans-10, cis-12 CLA in milk fat when fed high-concentration diets low in dietary cis9,cis-12 C18:2 (Sandri et al., 2020). It cannot be ruled out that other mechanisms were at play, including the effect of unidentified isomers capable of MFD (Perfield et al., 2007).
Typically, concentration of de novo FA (i.e., from mammary origin) decrease during MFD, whereas concentration of preformed FA (i.e., from the circulation) increase (Ramirez Ramirez et al., 2015; Rico et al., 2015). The relationship between trans-10,cis-12 CLA or trans-10 C18:1 in milk and de novo FA concentration in milk is negative, whereas the relationship with the proportion of preformed FA is positive (Bauman and Griinari, 2001). In our study, a trend for increased concentration of de novo and mixed FA (16-carbon; half derived from de novo synthesis in the mammary gland and the other half from the circulation) was observed when MG was added to the diets compared with the CTRL group. Increased rumen accumulation of trans-10 isomers was reported in some experiments when feeding a high fat and starch diet to dry and lactating cows (Zened et al., 2013; Ramirez Ramirez et al., 2015). The increase in trans-11 C18:1 during Mg-supplementation period in the magnesium-fed animals, and also the increased de novo FA in the MG diet, suggested that the rumen shifts back to the normal $\mathrm{BH}$ pathway, whereas a greater concentration of trans-10 C18:1, a key marker of the altered $\mathrm{BH}$ pathway, was observed in the CTRL group. In addition, supplementation of magnesiumbased alkalizers resulted in a lower trans-10:trans-11 ratio within $48 \mathrm{~h}$ of supplementation, which remained low during the rest of the Mg-supplementation period (the first $5 \mathrm{~d}$ of this period). Alterations in trans-10 C18:1 are commonly associated with cases of MFD and altered $\mathrm{BH}$ in the rumen, with trans-10 C18:1 acting as an intermediate in the alternative $\mathrm{BH}$ pathway (Lock et al., 2007; Lascano et al., 2016). Although this isomer is not a direct cause of MFD, it is often used as a proxy for cases of MFD and persistence of the altered BH pathway (Lock et al., 2007). The trans-11 C18:1 isomer associated with the normal BH pathway is a substrate of the desaturation of cis-9,trans-11 CLA (Harvatine et al., 2009a). In our previous study, a tendency to decrease the yield of total trans-FA in milk was observed when cows were fed magnesium oxide and calcium-magnesium dolomite, whereas we observed a decrease in the yield of trans-10 C18:1 and an increase in the yield of trans-11 C18:1 in milk fat compared with nonsupplemented diet (Razzaghi et al., 2021). Remarkably, the concentrations of cis-9,cis-12 C18:2 and cis9,trans-11 CLA were not affected by magnesium-based alkalizers, in contrast to previous observations in the recovery of MFD, where the concentrations of trans-11 C18:1 and cis-9,trans-11 CLA were similarly affected (Rico et al., 2015). In the current study, the reason for the lack of simultaneous changes in these 2 isomers is unclear, but it could be related to the lower PUFA loading compared with previous MFD recovery studies. 


\section{CONCLUSIONS}

Overall, a diet containing magnesium-based alkalizers improved milk fat concentration and yield within 4 $\mathrm{d}$ of supplementation in lactating dairy cows that experienced biohydrogenation-induced MFD. Responses to milk fat synthesis remained greater for $7 \mathrm{~d}$ after cessation of supplementation, whereas this positive effect disappeared from $8 \mathrm{~d}$ after cessation of magnesium supplementation until the end of the experiment. The difference in milk fat concentration and yield was associated with lower and greater concentrations of trans-10 and trans-11 C18:1, respectively, during the experiment. This suggested that the effect of magnesium-based alkalizers on milk fat synthesis was mediated by a shift in the ruminal C18:2 biohydrogenation pathway. The shifts in FA profile indicated that dietary magnesium oxide and calcium-magnesium dolomite restored milk fat synthesis by promoting the normal BH pathway and reducing flux through the alternative pathway. Therefore, calcium-magnesium dolomite and magnesium oxide have a similar ability to improve milk fat synthesis in dairy cows under MFD conditions.

\section{ACKNOWLEDGMENTS}

This experiment was conducted at the Research Farm of the Faculty of Agriculture, Ferdowsi University of Mashhad (Mashhad, Iran) in 2019. Partial funding was provided by the Department of Animal Science, Faculty of Agriculture, Ferdowsi University of Mashhad, Iran (grant no. 98112). This work was also supported by the Nutri-Paya Science-based Co. (Center of Innovation, Ferdowsi University of Mashhad). The authors express their appreciation to A. Madaeni (a farm staff at Research Center of Dairy Cow, Ferdowsi University of Mashhad) for technical assistance and H. Ghorbani Farmad (farm staff at Astan-e-Razavi Dairy Farm, Mashhad, Iran) for assistance with sample collection. We also acknowledge Dordaneh Khorasan-e-Razavi (Animal and Poultry Feed Co., Razavi Khorasan Province, Mashhad, Iran) for the preparation of the superconditioned corn. The authors have not stated any conflicts of interest.

\section{REFERENCES}

Alfonso-Avila, A. R., E. Charbonneau, P. Y. Chouinard, G. F. Tremblay, and R. Gervais. 2017. Potassium carbonate as a cation source for early-lactation dairy cows fed high-concentrate diets. J. Dairy Sci. 100:1751-1765. https://doi.org/10.3168/jds.2016-11776.

AOAC International. 2005. Official Methods of Analysis, 18th ed. AOAC International.

Bach, A., I. Guasch, G. Elcoso, J. Duclos, and H. Khelil-Arfa. 2018. Modulation of rumen $\mathrm{pH}$ by sodium bicarbonate and a blend of different sources of magnesium oxide in lactating dairy cows sub- mitted to a concentrate challenge. J. Dairy Sci. 101:9777-9788. https://doi.org/10.3168/jds.2017-14353.

Bauman, D. E., and J. M. Griinari. 2001. Regulation and nutritional manipulation of milk fat: Low-fat milk syndrome. Livest. Prod. Sci. 70:15-29. https://doi.org/10.1016/S0301-6226(01)00195-6.

Baumgard, L. H., B. A. Corl, D. A. Dwyer, A. Sæbø, and D. E. Bauman. 2000. Identification of the conjugated linoleic acid isomer that inhibits milk fat synthesis. Am. J. Physiol. Regul. Integr. Comp. Physiol. 278:R179-R184. https://doi.org/10.1152/ajpregu 2000.278.1.R179.

Cabrita, A. R. J., J. M. P. Vale, R. J. B. Bessa, R. J. Dewhurst, and A. J. M. Fonseca. 2009. Effects of dietary starch source and buffers on milk responses and rumen fatty acid biohydrogenation in dairy cows fed maize silage-based diets. Anim. Feed Sci. Technol. 152:267-277. https://doi.org/10.1016/j.anifeedsci.2009.04.020.

Calsamiglia, S., A. Ferret, J. Plaixats, and M. Devant. 1999. Effect of $\mathrm{pH}$ and $\mathrm{pH}$ fluctuations on microbial fermentation in a continuous culture system. J. Dairy Sci. 82(Suppl.1):38.

Chouinard, P. Y., L. Corneau, D. M. Barbano, L. E. Metzger, and D. E. Bauman. 1999. Conjugated linoleic acids alter milk fatty acid composition and inhibit milk fat secretion in dairy cows. J. Nutr. 129:1579-1584. https://doi.org/10.1093/jn/129.8.1579.

Christie, W. W. 1982. A simple procedure for rapid transmethylation of glycerol-lipids and cholesteryl esters. J. Lipid Res. 23:1072-1075. https://doi.org/10.1016/S0022-2275(20)38081-0.

Crawford, G. I., C. D. Keeler, J. J. Wagner, C. R. Krehbiel, G. E. Erickson, M. B. Crombie, and G. A. Nunnery. 2008. Effects of calcium magnesium carbonate and roughage level on feedlot performance, ruminal metabolism, and site and extent of digestion in steers fed high-grain diets. J. Anim. Sci. 86:2998-3013. https://doi .org/10.2527/jas.2007-0070.

Dewanckele, L., L. Jing, B. Stefańska, B. Vlaeminck, J. Jeyanathan, W. M. Van Straalen, A. Koopmans, and V. Fievez. 2019. Distinct blood and milk 18-carbon fatty acid proportions and buccal bacterial populations in dairy cows differing in reticulorumen $\mathrm{pH}$ response to dietary supplementation of rapidly fermentable carbohydrates. J. Dairy Sci. 102:4025-4040. https://doi.org/10.3168/jds .2018-15823.

Dijkstra, J., J. Ellis, E. Kebreab, A. Strathe, S. Lopez, J. France, and A. Bannink. 2012. Ruminal pH regulation and nutritional consequences of low pH. Anim. Feed Sci. Technol. 172:22-33. https:// doi.org/10.1016/j.anifeedsci.2011.12.005.

Erdman, R. A. 2011. Monitoring feed efficiency in dairy cows using fat-corrected milk per unit dry matter intake. Pages 69-79 in Proc. Mid-Atlantic Nutrition Conference, University of Maryland, College Park. Mid-Atlantic Feed Industry Council.

Erdman, R. A., R. Hemken, and L. Bull. 1982. Dietary sodium bicarbonate and magnesium oxide for early postpartum lactating dairy cows: Effects of production, acid-based metabolism, and digestion. J. Dairy Sci. 65:712-731. https://doi.org/10.3168/jds.S0022 $-0302(82) 82259-5$.

Fuentes, M. C., S. Calsamiglia, P. Cardozo, and B. Vlaeminck. 2009. Effect of $\mathrm{pH}$ and level of concentrate in the diet on the production of biohydrogenation intermediates in a dual-flow continuous culture. J. Dairy Sci. 92:4456-4466. https://doi.org/10.3168/jds .2008-1722.

Goff, J. P. 2018. Invited review: Mineral absorption mechanisms, mineral interactions that affect acid-base and antioxidant status, and diet considerations to improve mineral status. J. Dairy Sci. 101:2763-2813. https://doi.org/10.3168/jds.2017-13112.

Hall, M. B., W. H. Hoover, J. P. Jennings, and T. K. Miller-Webster. 1999. A method for partitioning neutral detergent-soluble carbohydrates. J. Sci. Food Agric. 79:2079-2086. https://doi.org/10.1002/ (SICI)1097-0010(199912)79:15<2079::AID-JSFA502>3.0.CO;2-Z.

Harrison, J., R. White, R. Kincaid, E. Block, T. Jenkins, and N. StPierre. 2012. Effectiveness of potassium carbonate sesquihydrate to increase dietary cation-anion difference in early lactation cows. J. Dairy Sci. 95:3919-3925. https://doi.org/10.3168/jds.2011-4840.

Harvatine, K. J., Y. R. Boisclair, and D. E. Bauman. 2009a. Recent advances in the regulation of milk fat synthesis. Animal 3:40-54. https://doi.org/10.1017/S1751731108003133. 
Harvatine, K. J., I. W. Perfield II, and D. E. Bauman. 2009b. Expression of enzymes and key regulators of lipid synthesis is upregulated in adipose tissue during CLA-induced milk fat depression in dairy cows. J. Nutr. 139:849-854. https://doi.org/10.3945/jn.108 .099994 .

Iranian Council of Animal Care. 1995. Guide to the Care and Use of Experimental Animals. Vol. 1. Isfahan University of Technology.

Jenkins, T. C., R. J. Wallace, P. J. Moate, and E. E. Mosley. 2008. Board-invited review: Recent advances in biohydrogenation of unsaturated fatty acids within the rumen microbial ecosystem. J. Anim. Sci. 86:397-412. https://doi.org/10.2527/jas.2007-0588.

Kalscheur, K. F., B. B. Teter, L. S. Piperova, and R. A. Erdman. 1997. Effect of dietary forage concentrate and buffer addition on duodenal flow of trans-C18:1 fatty acids and milk fat production in dairy cows. J. Dairy Sci. 80:2104-2114. https://doi.org/10.3168/ jds.S0022-0302(97)76156-3.

Khorasani, G. R., and J. J. Kennelly. 2001. Influence of carbohydrate source and buffer on rumen fermentation characteristics, milk yield, and milk composition in late-lactation Holstein cows. J. Dairy Sci. 84:1707-1716. https://doi.org/10.3168/jds.S0022 -0302(01)74606-1.

Lascano, G. J., M. Alende, L. E. Koch, and T. C. Jenkins. 2016. Changes in fermentation and biohydrogenation intermediates in continuous cultures fed low and high levels of fat with increasing rates of starch degradability. J. Dairy Sci. 99:6334-6341. https:// doi.org/10.3168/jds.2016-11032.

Le Ruyet, P., and W. B. Tucker. 1992. Ruminal buffers: Temporal effects on buffering capacity and $\mathrm{pH}$ of ruminal fluid from cows fed a high concentrate diet. J. Dairy Sci. 75:1069-1077. https://doi.org/ 10.3168/jds.S0022-0302(92)77851-5.

Lock, A. L., C. Tyburczy, D. A. Dwyer, K. J. Harvatine, F. Destaillats, Z. Mouloungui, L. Candy, and D. E. Bauman. 2007. Trans-10 octadecenoic acid does not reduce milk fat synthesis in dairy cows. J. Nutr. 137:71-76. https://doi.org/10.1093/jn/137.1.71.

Luna, P., M. Juárez, and M. A. de la Fuente. 2005. Validation of a rapid milk fat separation method to determine the fatty acid profile by gas chromatography. J. Dairy Sci. 88:3377-3381. https:/ /doi.org/10.3168/jds.S0022-0302(05)73021-6.

Ma, G., J. H. Harrison, E. Block, T. C. Jenkins, and L. Van Wieringen. 2017. Short communication: Temporal effect of feeding potassium carbonate sesquihydrate on milk fat in lactating dairy cows fed a fat-depressing diet. J. Dairy Sci. 100:371-378. https://doi .org/10.3168/jds.2016-11205.

Malekkhahi, M., A. A. Naserian, A. Rahimi, A. Bazgir, D. Vyas, and A. Razzaghi. 2021. Effects of ground, steam-flaked, and superconditioned corn grain on production performance and total-tract digestibility of dairy cows. J. Dairy Sci. 104:6756-6767. https://doi .org/10.3168/jds.2020-19202.

Matamoros, C., R. N. Klopp, L. E. Moraes, and K. J. Harvatine. 2020. Meta-analysis of the relationship between milk trans-10 C18:1, milk fatty acids $<16 \mathrm{C}$, and milk fat production. J. Dairy Sci. 103:10195-10206. https://doi.org/10.3168/jds.2019-18129.

Mills, H. A., and J. B. Jones Jr. 1996. Plant Analysis Handbook II: A Practical Sampling, Preparation, Analysis, and Interpretation Guide. Micro-Macro Publishing Inc.

Mohammed, R., J. J. Kennelly, J. K. G. Kramer, K. A. Beauchemin, C. S. Stanton, and J. J. Murphy. 2010. Effect of grain type and processing method on rumen fermentation and milk rumenic acid production. Animal 4:1425-1444. https://doi.org/10.1017/ S175173111000039X.

Morris, T. R. 1999. Experimental design and analysis in animal sciences. CABI Publishing.

National Research Council (NRC). 2001. Nutrient Requirements of Dairy Cattle, 7th revised ed., National Academic Press.

Neville, E. W., A. G. Fahey, V. P. Gath, B. P. Molloy, S. J. Taylor, and F. J. Mulligan. 2019. The effect of calcareous marine algae, with or without marine magnesium oxide, and sodium bicarbonate on rumen $\mathrm{pH}$ and milk production in mid-lactation dairy cows. J. Dairy Sci. 102:8027-8039. https://doi.org/10.3168/jds.2019-16244.

Orth, R. 1992. Sample day and lactation report. DHIA 200 Fact Sheet A-2. Mid-states DRPC.
Perfield, J. W. II, A. L. Lock, J. M. Griinari, A. Saebo, P. Delmonte, D. A. Dwyer, and D. E. Bauman. 2007. Trans-9, cis-11 conjugated linoleic acid reduces milk fat synthesis in lactating dairy cows. J. Dairy Sci. 90:2211-2218. https://doi.org/10.3168/jds.2006-745.

Ramirez Ramirez, H. A., E. C. Lopez, K. J. Harvatine, and P. J. Kononoff. 2015. Fat and starch as additive risk factors for milk fat depression in dairy diets containing corn dried distillers grains with solubles. J. Dairy Sci. 98:1903-1914. https://doi.org/10.3168/jds .2014-8528.

Rauch, R., P. Robinson, and L. Erasmus. 2012. Effects of sodium bicarbonate and calcium magnesium carbonate supplementation on performance of high producing dairy cows. Anim. Feed Sci. Technol. 177:180-193. https://doi.org/10.1016/j.anifeedsci.2012 .08 .016 .

Razzaghi, A. 2021. "Feed intake and milk production and composition in cows fed a milk fat-depressing (MFD) diet supplemented or not with magnesium-based alkalizers." Mendeley Data, V1. https:// doi.org/10.17632/ngszd7jrtz.1.

Razzaghi, A., M. Malekkhahi, R. Valizadeh, E. Parand, and A. R. Bayat. 2021. Modulation of ruminal $\mathrm{pH}$, milk fat secretion, and biohydrogenation intermediates by alkalizing agents in dairy cows fed starch-rich diets. Livest. Sci. 248:104485-104493. https://doi .org/10.1016/j.livsci.2021.104485.

Razzaghi, A., R. Valizadeh, M. H. Ghaffari, and A. F. Brito. 2020. Liquid molasses interacts with buffers to affect ruminal fermentation, milk fatty acid profile, and milk fat synthesis in dairy cows fed high-concentrate diets. J. Dairy Sci. 103:4327-4339. https:// doi.org/10.3168/jds.2019-17169.

Rico, D. E., and K. J. Harvatine. 2013. Induction of and recovery from milk fat depression occurs progressively in dairy cows switched between diets that differ in fiber and oil concentration. J. Dairy Sci. 96:6621-6630. https://doi.org/10.3168/jds.2013-6820.

Rico, D. E., A. W. Holloway, and K. J. Harvatine. 2015. Effect of diet fermentability and unsaturated fatty acid concentration on recovery from diet-induced milk fat depression. J. Dairy Sci. 98:79307943. https://doi.org/10.3168/jds.2014-8990.

Sandri, E. C., J. Lévesque, A. Marco, Y. Couture, R. Gervais, and D. E. Rico. 2020. Transient reductions in milk fat synthesis and their association with the ruminal and metabolic profile in dairy cows fed high-starch, low-fat diets. Animal 14:2523-2534. https://doi .org/10.1017/S1751731120001585.

Schaefer, D. M., L. J. Wheeler, C. H. Noller, R. B. Keyser, and J. L. White. 1982. Neutralization of acid in the rumen by magnesium oxide and magnesium carbonate. J. Dairy Sci. 65:732-739. https:/ /doi.org/10.3168/jds.S0022-0302(82)82260-1.

Shingfield, K. J., and J. M. Griinari. 2007. Role of biohydrogenation intermediates in milk fat depression. Eur. J. Lipid Sci. Technol. 109:799-816. https://doi.org/10.1002/ejlt.200700026.

Sukhija, P. S., and D. L. Palmquist. 1988. Rapid method for determination of total fatty acid content and composition of feedstuffs and feces. J. Agric. Food Chem. 36:1202-1206. https://doi.org/10 $.1021 / \mathrm{jf00084a019.}$

Thomas, J. W., and R. S. Emery. 1969. Additive nature of sodium bicarbonate and magnesium oxide on milk fat concentrations of milking cows fed restricted roughage rations. J. Dairy Sci. 52:17621769. https://doi.org/10.3168/jds.S0022-0302(69)86838-4.

Van Soest, P. J., J. B. Robertson, and B. A. Lewis. 1991. Methods of dietary fiber, neutral detergent fiber, and non-starch polysaccharides in relation to animal nutrition. J. Dairy Sci. 74:3583-3597. https://doi.org/10.3168/jds.S0022-0302(91)78551-2.

Yu, P., T. Huber, F. A. P. Santos, J. M. Simas, and C. B. Theurer. 1998. Effects of ground, steam-flaked, and steam-rolled corn grains on performance of lactating cows. J. Dairy Sci. 81:777-783. https: //doi.org/10.3168/jds.S0022-0302(98)75634-6.

Zened, A., F. Enjalbert, M. C. Nicot, and A. Troegeler-Meynadier. 2013. Starch plus sunflower oil addition to the diet of dry dairy cows results in a trans-11 to trans-10 shift of biohydrogenation. J. Dairy Sci. 96:451-459. https://doi.org/10.3168/jds.2012-5690. 